\title{
PENINGKATAN KETERAMPILAN NENULIS PUISI BEBAS MELALUI PENDEKATAN KONSTRUKTIVISME
}

\author{
Like Suoth \\ Universitas Halmahera \\ rinogirato87@yahoo.com
}

\begin{abstract}
Abstrak
Penelitian ini bertujuan untuk meningkatkan keterampilan menulis puisi bebas melalui pendekatan konstruktivisme. Metode yang digunakan dalam penelitian ini yaitu metode deskriptif kualitatif dan kuantitatif. Penelitian kualitatif bertujuan untuk mendeskripsikan atau menjelaskan data secara sistematik berupa kalimat yang berhubungan dengan hasil belajar siswa dan penelitian kuantitatif dapat dilihat dari nilai kemampuan siswa dalam menulis puisi bebas. Data dianalisis dengan menggunakan analisis dekriptif. Subjek penelitiaan ini adalah siswa kelas VI SD Katolik Poigar yang berjumlaah 20 siswa, terdiri dari 8 laki-laki dan 12 perempuan. Jenis penelitian ini adalah penelitian tindakan kelas (PTK). Hasil penelitiaan menunjukkan bahwa nilai rata-rata pembelajaran menulis puisi bebas melalui pendekataan konstruktivisme pada siklus I belum menunjukkan hasil yang signifikkan dan nilai yang diperoleh belum sesuai dengan KKM. Dari 20 siswa yang menulis puisi bebas terdapat 11 siswa yang belum mampu menulis puisi dan memiliki nilai tertinggi terendah 50, sedangkan 9 siswa belum mampu menulis puisi bebas serta memiliki nilai 80 dan jika nilai tersebut dirata-ratakan menjadi 74,60 belum mencapai nilai KKM 75 dan berada pada kategori cukup. Pada siklus II menunjukkan hasil yang sangat baik. Nilai yang diperoleh sesuai dengan yang diharapkan. Dari 20 siswa yang menulis puisi bebas memiliki nilai tertinggi 90 dan jika dirata-ratakan menjadi 82,2 ini berarti siswa telah berhasil menulis puisi bebas dan sesuai dengan standar KKM 75 dan berada pada kategori baik.
\end{abstract}

Kata Kunci:, keterampilan menulis, puisi bebas, dan konstruktivisme

\begin{abstract}
The aimed of this study is improve the skills of free poetry writing through constructivism approach. The method used in this research is descriptive qualitative and quantitative methods. Qualitative research aims to describe or explain the data systematically in the form of sentences relating to student learning outcomes and quantitative research can be seen from the value of students' ability in writing free poetry. The data analyzed by using descriptive analysis. The subjects of this research are the sixth grade students of Poigar Catholic Primary School which consist of 20 students, consisting of 8 males and 12 females whereas, this research type is research of class action (PTK). The result of this research is that the average value of free writing poetry learning through constructivism alignment in the first cycle has not shown significant results and the nilai obtained is not as correct as the KKM. Of the 20 students who wrote free poetry there were 11 students who had not been able to write poetry and had the lowest score of 50 while, 9 students had not been able to write free poetry and had a value of 80 and if the value is averaged to 74.60 has not reached KKM 75 and are in enough category, while in cycle II showed very good result. Value earned as expected. Of the 20 students who write free poems have the highest score of 90 and if averaged to 82.2 this means that students have succeeded in writing free poems and in accordance with KKM standard 75 and are in good category.
\end{abstract}

Keywords:, writing skill, free poetry, and constructivism

\section{Pendahuluan}

Dalam kegiatan pembelajaran komponen peserta didik dan pendidik merupakan hal yang penting dalam proses pembelajaran karena dalam proses pembelajaran terjadi interaksi antara guru dan siswa. Di dalam komponen pengajaran terdapat empat aspek keterampilan berbahasa yang sangat berpengaruh dalam berbahasa untuk berkomunikasi. Aspek berbahasa diantaranya yaitu, keterampilan menyimak, membaca, menulis dan berbicara.

Dari keempat aspek tersebut yang sangat berpengaruh dalam pembelajaran menulis yaitu aspek keterampilan menulis. Menulis merupakan salah satu keterampilan berbahasa yang harus dimiliki oleh siswa. Dengan menulis siswa dapat mengungkapkan dan mengekspresikan gagasan, atau pendapat, pemikiran, dan perasaan yang dimiliki. Selain itu, dapat mengembangkan daya pikir dan kreativitas siswa dalam menulis (Slamet, 2012). Salah satu keterampilan, menulis dalam pembelajaran bahasa Indonesia yaitu, keterampilan menulis puisi. Puisi merupakan bentuk karya sastra yang mengungkapkan pikiran dan perasaan penyair serta imajinatif dan disusun dengan mengkosentrasikan semua kekuatan bahasa dengan struktur fisik dan struktur batinnya (Waluyo, 1995). 
Selanjutnya, salah satu pendekatan yang dapat diterapkan dalam menulis puisi yaitu pembelajaran dengan menggunakan pendekatan konstruktivisme. Pendekatan ini pada dasarnya diterapkan kepada siswa untuk belajar membangun pengetahuan mereka lewat keterlibatan aktif dalam proses belajar menjagar yang bersifat student centered daripada teacher centered. Sebagian besar waktu belajar mengajar berlangsung dengan berbasis pada aktivitas siswa. Dengan dasar itu, pembelajaran harus dikemas mejadi proses "mengontruksikan" bukan "menerima” pengetahuan.

Berdasarkan hasil observasi peneliti di kelas VI SD Katolik Poigar dalam pembelajaran menulis puisi bebas belum mampu menulis puisi dari 20 siswa yang menulis puisi terdapat 15 siswa yang belum mampu dan 5 siswa mampu menulis puisi bebas. Hal ini disebabkan karena guru kurang berperan aktif dalam pembelajaran, pendekatan pembelajaran yang digunakan guru tidak disukai oleh siswa dan guru tidak kretif dalam pembelajaran serta guru tidak memberikan kesempatan kepada siswa utuk mengungkapkan gagasan dengan menggunakan bahasa siswa sendiri.

Penelitian ini dapat memberikan solusi bagi guru dalam meningkatkan kemampuan siswa dalam menulis. Oleh karena itu, guru dapat menerapkan pendekatan kontruktivisme dan pendekatan lainnya dalam proses pembelajaran di dalam kelas.

\section{Metode}

Metode yang digunakan dalam penelitian ini adalah metode deskripsi kualitatif dan kuantitatf sedangkan, jenis penelitian tindakan kelas (PTK) yang dirancang menggunakan siklus N. Dikatakan penelitian kuantitatif karena berwujud nilai kemampuan menulis puisi dan dapat dianalisis dengan menggunakan analisis deskriptif.

Ada beberapa prosedur penelitian yang harus dilakukan, yaitu: tahap-tahap penelitian tindakan kelas. Menurut Kemmis dan Taggart (dalam Rafi'uddin, 1996) penelitian tindakan dapat dipandang sebagai suatu siklus spriral dari penyusunan, perencanaan, pelaksanaan tindakan, pengamatan (observasi), dan refleksi.

Teknik yang digunakan dalam penelitian ini sebagai berikut:

1. Pengamatan (observasi)

Observasi dilakukan pada siswa kelas VI SD Katolik Poigar yang berjumlah 20 siswa. Sebelum penelitian, peneliti melakukan observasi terlebih dahulu di kelas pada saat proses pembelajaran menulis puisi bebas. Setelah observasi selesai maka peneliti dapat mengambil sebuah kesimpulan tentang kemampuan menulis puisi bebas dan kemampuan siswa dalam menulis puisi masih rendah sehingga peneliti mengadakan penelitian tersebut.

2. Tes (test)

Tes sebagi instrumen data melalui beberapa pertanyaan atau latihan terlebih dahulu yang digunakan adalah mengukur keterampilan pengetahuan, intelegensi, dan kemampuan bakat yang dimiliki oleh individu atau kelompok. Peneliti menyebarkan soal tes tertulis kepada siswa kelas VI yang berjumlah 20 siswa. Tes dilakukan di dalam kelas sesuai dengan jadwal yang telah ditentukan.

Teknik Analisis Data

1. Tahap analisis data Kuantitatif

a. Persiapan: mengecek nama, dan isi data.

b. Tabulasi: memberi skor, memberi cek, dan mengubah jenis data.

c. Penerapan data sesuai pendekatan penelitian yaitu konstruktivisme.

d. Penelitian deskrisi: nilai yang diperoleh melalui hitungan persentase dikategorikan sesuai dengan kriteria yang telah ditentukan.

Rumus persentase dari Aqib (2010:40) untuk mengukur kemampuan siswa dalam menulis puisi bebas.

Data kualitatif diperoleh dari lembar observasi aktivitas siswa dalam menulis puisi bebas, selama proses pembelajaran menulis puisi bebas melalui pendekatan pembelajaran konstruktivisme. Poerwanti (2008) menerangkan cara untuk mengolah data skor sebagai berikut:

(1) Menentukan skor terendah

(2) Menentukan skor tertinggi

(3) Mencari media

(4) Membagi rentang nilai menjadi 4 kategori (sangat baik, baik, cukup, dan kurang). 


\section{Hasil Penelitian dan Pembahasan}

Pembelajaran menulis puisi bebas dengan pendekatan konstruktivisme meliputi tahap prapenulisan, tahap penulisan, dan tahap revisi. Tindakan menulis puisi dilaksanakan dalam 2 siklus. Setiap tahap berlangsung dalam 3 kali pertemuan dan setiap pertemuan dilaksanakan dua jam pelajaran.

Peningkatan keterampilan menulis puisi bebas melalui pendekatan konstruktivisme pada siklus I. Hasil penelitian pada siklus I dilakukan berdasarkan kegiatan yang dilaksanakan yakni, perencanaan tindakan, pelaksanaan pembelajaran, dan refleksi. Dari 20 siswa yang menulis puisi bebas terdapat 6 siswa yang memperoleh nilai 80 sedangkan, yang memperoleh nilai 70 dan 61 sebanyak 8 siswa dan yang 6 siswa mendapat nilai di bawah 60. Jika dihitung menggunakan rumus persentase dapat nilai rata-rata siswa adalah 74,60. Nilai 74,60 belum mencukupi nilai KKM.

Peningkatan keterampilan menulis puisi bebas melalui pendekatan konstruktivisme pada siklus II. Analisis data kemampuan menulis puisi bebas melalui pendekatan konstruktivisme pada siklus II menunjukkan hasil yang signifikan. Pada siklus I hasil tes yang dicapai siswa jika dirata-ratakan 74,60. Akan tetapi, pada siklus II nialai tertinggi siswa yang diperoleh sangat memuaskan dan jika dirata-ratakan menjadi 82,2 sudah melebihi nilai standar KKM yaitu 75 .

Pembahasan hasil penelitian dilakukan berdasarkan II siklus berdasarkan kegiatan yang dilakukan yaitu prapenulisan, tahap pemburaman, dan tahap revisi. Hasil tindakan peningkatan keterampilan menulis puisi bebas melalui pendekatan konstruktivisme dilakukan melalui tahap prapenulisan yaitu siswa dituntut untuk mampu menulis puisi fdilaksanakan dari awal menentukan judul sampai pada kemampuan pengungkapkan pendapat. Tahap kedua yaitu tahap pemburaman. Melalui tahap ini siswa mengembangkan gagasan mereka lewat judul yang mereka pilih dan membentuk sebuah puisi yang buram. Ketiga tahap revisi yaitu, siswa dituntut agar merevisi puisi hasil temannya mulai dari pemilihan judul, kedalaman gagasan, diksi, dan tipografi yang dituliskan oleh siswa yang lain.

Implikasi dari penelitian ini yaitu untuk perbaikan kualitas pembelajaran bahasa indonesia. Pembelajaran bahasa indonesia dengan menggunakan pendekatan konstruktivisme dapat digunakan sebagai teknik pemecahan masalah yang dialami oleh guru dan siswa di dalam kelas pada proses pembelajaran. Pendekatan ini menjadikan guru mampu terampil, kreatif, inovatif dalam mengajar sehingga siswa berhasil dalam menulis puisi.

\section{Kesimpulan}

Berdasarkan hasil penelitian dapat disimpulkan bahwa peningkatan keterampilan menulis puisi bebas dengan pendekatan konstruktivisme pada siswa kelas VI SD Poigar penelitian ini sangat berdampak positif terhadap keberhasilan siswa dalam menulis puisi.

Berdasarkan hasil penelitian keterampilan menulis puyisi bebas melalui pendekatan konstruktivisme pada siswa kelas VI SD Katolik Poigar. Saran dalam penelitian ini yaitu, pendekatan konstruktivisme dapat memberikan alterlatif dalam proses pembelajaran menulis puisi bebas. Pembelajaran ini dapat memberikan kesempatan kepada siswa untuk berpikir kritis dan proses mencari pengetahuan melalui pengalaman. Pembelajaran ini juga dapat memberikan kepada siswa untuk mengungkapkan gagasan yang mereka dapat dengan menggunakan bahasa mereka sendiri.

\section{Daftar Pustaka}

Alfiah. (2009). Pengajaran Puisi. Yogyakarta: Pustaka Pelajar

Aqib, Zainal. (2010). Penelitian Tindakan Kelas. Bandung:Yrama Widya

Aminudin. (1987). Pengantar Apresiasi Karya Sastra. Jakarta|: Sinar Baru

Baharuddin. (2008). Teori Belajar dan Pembelajarn. Yogyakarta: Ar-Ruzz

Bell. (1995). Belajar dan Pembelajaran (terjemahan). Jakarta: PT Rajawali Pers

Direktorat. (2010). Pembelajarn Kontekstual Peningkatan Mutu Pendidikan dan Tenaga Kependidikan.

Jakarta: Pustaka

Djojosuroto. (2009). Teori dan Pembelajaran Puisi. Yogyakarta: Pustaka

Hanafi. (2010). Konsep Strategi Pembelajaran. Bandung: Refika Afitama

Lintong. (2010). Gagasan-gagasan Pendidikan Kontemporer Pemberdayaan Mutu Pendidikan Indonesia. Yogyakarta: Cahaya Pineleng

Muthih. (2008). Pembelajaran Kontekstual. Semarang: Rasali Media Group 
Rafi'uddin. (1996). Rancangan Penelitian Tindakan Makalah Disajikan dalam Lokakarya Tingkat Lanjut Penelitian Kualitatif. Angkatan ke V. Malang: OLIP

Sanjaya. (2006). Strategi Pembelajaran Berorientasi Standar Proses Pendidikan. Jakarta: Kenana Predana Media Group

Slamet. (2012). Dasar-dasar Keterampilan Berbahasa Indonesia. Surakarta: UNS Press

Sudjana. (1992). Metode Statistika. Bandung: Tarsito

Sugiyono. (2010). Metode Penelitian Kuantitatif., Kualitatif dan R \& D. Alfabet

Tarigan. (1986). Prinsip-prinsip Dasar Sastra. Bandung. Anggaksa

Waluyo. (1995). Teori dan Apresiasi Puisi. Jakarta: Gramedia 